\title{
ÖNTÉSZETI SZERSZÁM TERVEZÉSE ÉS SZÁMÍTÓGÉPPEL SEGÍTETT GYÁRTÁSA
}

\section{CASTING TOOL DESIGN AND COMPUTER-AIDED MANUFACTURING}

\author{
Géresi Zoltán Gergő, ${ }^{1}$ Gábora András ${ }^{2}$ \\ Debreceni Egyetem, Müszaki Kar, Debrecen, Magyarország \\ ${ }^{1}$ zoltan.geresi@eng.unideb.hu \\ ${ }^{2}$ andras.gabora@eng.unideb.hu
}

\begin{abstract}
Designing a casting tool and choosing materials technology parameters calls for special requirements both for workpiece and tool side. After designing the technological steps and procedures I select the cutting tools. Industrial developments take priority in cloud system engineering. I used this system in the casting tool manufacturing process. It is not easy to make a comprehensive and detailed design following technological steps. The allowances and joints were made on the M2L CNC milling machine. The CAM program was made with EdgeCam software. Defining the casting parameters accurately is still a challenge, but in our major it is not the most important. For the future we are planning a most complicated casting tool.
\end{abstract}

Keywords: casting, tool, design, CNC, manufacturing.

\section{Összefoglalás}

Egy öntészeti szerszám tervezésénél nagyon fontos követelmény az anyagtechnológiai paraméterek helyes megválasztása mind a munkadarab-, mind a szerszámoldalról. A technológiai sorrend és az adott műveletek megtervezése után a szerszámválasztás következett. Az ipar folyamatos fejlődésével egyre nagyobb a hangsúly a felhőalapú gyártáson. Ezt az újdonságot alkalmaztam az öntőszerszám megvalósítása során. Nehezítő körülmény az átfogó és megfelelő részletességű tervezés és technológiai sorrend végiggondolása. A türéseket és illesztéseket az M2L CNC-marógépen munkáltam meg. A CAM-program az EdgeCam szoftverrel készült. Az öntési paraméterek pontos meghatározása még nagy kihívás, de jelenlegi szakunk tanulmányaiban ez hiányos. Szeretnénk a közeljövőben egy bonyolultabb, nagyobb geometriájú szerszámot készíteni.

Kulcsszavak: öntés, szerszám, tervezés, CNC, gyártás.

\section{1. Öntészeti szerszám tervezése}

Az öntés a fémből készült tárgyak alakadásának legősibb módja. Időszámításunk előtt három évezreddel már öntöttek bronztárgyakat. Az öntéstechnológia legfőbb jellemzője az öntendő tárgy alakadásának nagy szabadsága, amely a legbonyolultabb formájú alkatrészek előállítását is lehetővé teszi. Az eljárás előnye, hogy rideg, tehát képlékenyen nem alakítható anyagokból is lehet tárgyakat készíteni. Egyedi és tömeggyártásban egyaránt alkalmazható. Az adott termék tervezésénél elengedhetetlen, az ergonómia, a jó használhatóság és a tartósság. Számos szempont figyelembevételével szükséges megtervezni egy adott végfelhasználói eszközt.

Egy öntészeti szerszám tervezésénél nagyon fontos követelmény az anyagtechnológiai paraméterek helyes megválasztása mind a munkadarab-, mind a szerszámoldalról. A méretezés során a térfogatigény és zsugorodási tényező is elengedhetetlen a munkadarab szerszámformában elfoglalt helyét illetően. 
A technológiai sorrend és az adott múveletek megtervezése után a szerszámválasztás következik. A katalógusértékek alapján kiszámítva a technológiai paramétereket többféle szerszámra vonatkoztatva, a megfelelő szerszám kerül a szerszámgépekbe.

\subsection{PLM-módszer}

A tervezést a modern informatikai megoldások segítségével szerettem volna végrehajtani. Minden ipari formatervezést, amely előzetesen szabadkézi rajzból indul ki, egy élőképernyős monitoron hajtanak végre, hogy a megálmodott szabadkézi rajz visszaadja az elképzeléseket.

\section{Késztermék tervezése}

A tervezés során az Onshape felhőalapú, díjmentes online szoftvert használtam. A felhőalapú gyártás az ipar 4.0 vívmánya. Az ipari digitalizáció felváltja a papíralapú tervezést. A 3D-tervezés és a gyártástechnológiatervezés- (CAD/CAM) rendszerek kiváltják a papíralapú tervezést, és minimálisra szűkítik a gyártáshoz szükséges papíralapú dokumentációt.

Az ipari vállalatoknál első kézből értesülhet bármely vezető akár utazás közben is a gyárban zajló folyamatokról, ezáltal időt megtakarítva a vállalat számára. Nem szükséges az üzemben tartózkodnia ahhoz, hogy tisztában legyen a folyamatokkal, állásokkal vagy épp átállásokkal, készletekkel stb. Az Onshape esetében nem kizárólag számítógépen érhető el, hanem mobilapplikációban is. Ezáltal néhány szabad perc alatt áttekinthető a tervezés vagy a gyártás folyamata.

A kész termék ergonómiailag megfelelő kell, hogy legyen, így a sketchből kihúzással elért sarkos formát el kellett látni lekerekítésekkel. Az éles sarkok a felhasználó kezét felsérthetik, ha erősen megszorítja vagy kicsúszik a kezéből. Erre azt a megoldást találtam ki, bár a formája miatt stabil megfogást tesz lehetővé, hogy a külső éleket lekerekítéssel látom el. Először azt láttam megfelelőnek, hogy $3 \mathrm{~mm}$-es sugarú lekerekítést alkalmazok, de technológiai szempontból figyelembe

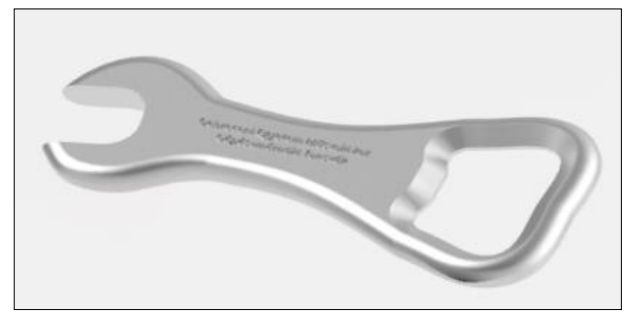

1. ábra. Kész termék (forrás: saját szerk.) kellett vennem, mi történik, ha negatív vagy pozitív irányban eltér a tűréstől a szerszám formamélysége. Ha pozitív irányban tér majd el, tehát nagyobb lesz, akkor marad egy érintetlen sáv az öntött mintában, amely nem okoz esztétikai problémát, és sérüléshez sem vezet. Ezzel szemben, ha negatívan tér el a forma mélysége, akkor, mivel összefut a két rádiusz, a lehetőség fennáll, hogy kialakuljon egy éles perem, amelyet utómunkálással el kell távolítani. Arra a döntésre jutottam, hogy 2,5 mm-re veszem a lekerekítési sugarat, és ezzel elkerülöm a gyártásból származó hibákat.

\section{3. Öntészeti szerszám tervezése}

A koncepcióm egy egyszerű gravitációs öntési technológiához alkalmas szerszám készítése volt, olyan beömlőnyílással, amely jól látható és hordozható bárki számára.

A célszerszámon a megrendelő neve is helyet kapott. Az ergonómiai szempontokat figyelembe véve, az éles, sarkos vagy letörésmenti éleket kerülni kell az eszköz tervezésénél. A termék kialakításánál törekedni kell arra, hogy az öntőformából minél könnyebben kivehető legyen a félkész termék, ezért az öntőszerszám általában 1-3ํk kúpossággal rendelkezik [1]. Az általam tervezett öntőforma oldalfalán szükséges kúpos felületeket 2,5 mm-es rádiuszos lekerekítéssel helyettesítettem, így az öntvényt könnyü eltávolítani a formából [2]. A beömlő tölcsért és a felöntés helyét is a tervezés fázisában kell meghatározni úgy, hogy az öntéskor zárványok ne keletkezhessenek, a formában lévő levegő el tudjon távozni az öntés közben. Jelen esetben a késztermék villáskulcs felőli oldalára helyeztem el mindkettőt. A szerszámforma felületminőségét is elő kell írni, $\mathrm{Rz}=3,16$ érdességet határoztam meg. A 1. ábrán látható a kész termék modellje, a 2. ábrán pedig az abból képezett háromformás öntőszerszám. A szerszámfelek összeszorítását két darab M8-csavarral biztosítottam. A szerszámok pozicionálását pedig két darab csappal oldottam meg, mely az egyik szerszámfélbe H7/m6-, míg a másik szerszámfélbe H7/f6-illesztéssel került beépítésre.

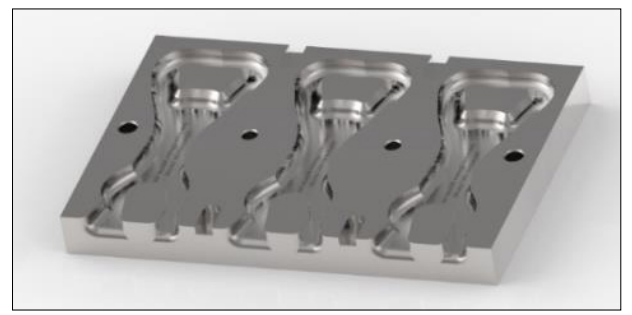

2. ábra. A szerszám modellje (forrás: saját szerk.) 
Az öntés befejeztével a szerszámfelek szétválasztásának megkönnyítését négy darab horony elhelyezésével oldottam meg, amelybe feszítésre alkalmas szerszám befér.

Mivel prototípusgyártásról van szó, a szerszámot ötvözetlen acélból készítettem (St52-1, DIN-anyagszám: 1.0052), az anyagköltséget így minimálisra szorítva. A gyártás során az erősen ötvözött acélok megkívánják a speciális szerszámokat. Ezáltal a gyártási költségek nőnek.

A szerszám konvertálása Onshape-ből parasolid-fájlként történt, amely magában hordozza az összes felületet spline-mentesen, így megszüntetve az utómunkát, azaz a spline-ok átkonvertálását. A munkadarabnullpont a munkadarab tetejeközepe volt. A biztonsági távolságot $20 \mathrm{~mm}$-re jelöltem ki, és innen indult minden munkafolyamat.

A megmunkálás beállításaiban határvonalakat kellett képezni: ezeket a program piros színnel jelöli (3. ábra). A megmunkálás teljes mélységen zajlott. A szerszámgép viselkedése feltűnően jó volt. A szerszámgép nem produkált túlzottan komoly rezgéseket, bár a burkolat kissé zajos volt. A simítás csak az oldalfalra terjedt ki, mert időközben kiderült, hogy praktikussági okokból a hullámformaminta tapadófelületként viselkedik, és kiválóan segíti a szerszám használatát. A simításhoz felületi érdességet kellett számolni, mert a nagyolt felület felületi hibáiba befolyhat az alumínium, és meggátolja az eltávolíthatóságot. A szerszám felületminőségét illetően a nagyolási technológia után durva felület marad.[3]

Elméleti felületi érdesség számítása:

$$
R_{t h}=\sqrt{\frac{d_{1}{ }^{2}-b_{r}{ }^{2}}{2}}
$$

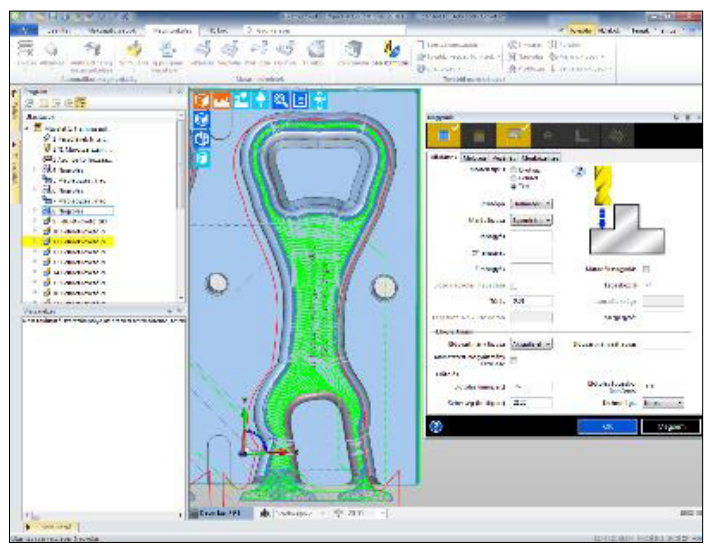

3. ábra. Hullámforma marással (forrás: saját szerk.)

$$
\begin{aligned}
b_{r} & =2 \cdot \sqrt{R_{t h} \cdot\left(d_{1}-R_{t h}\right)}= \\
& =2 \cdot \sqrt{0,0008 \cdot(6-0,0008)}=0,1385[\mathrm{~mm}]
\end{aligned}
$$

Az irányadó oldalra lépési értéket (4. ábra) használtuk fel a simításhoz generált pályához. Az így kapott eredmény egy nagyon szép, egyenletes felület. A szerszámiparban bevett szokás, hogy síkfelület-megmunkálás után egyszerűen lefektetik a szerszámgép asztalára, és speciális egyedi megfogást alkalmazva, úgynevezett papucsokkal szorítják az asztalhoz. Ennek a hátránya, hogy nagy erő hatására elmozdulhat marás közben. Mivel a gép felépítéséből adódóan nem szabott ilyen korlátot, így biztosan nem mozdíthatta ki a darabot a helyéről. A papucsokat viszonylag közel helyeztem a maráshoz, hogy maráskor ne érje nagy erőkar a munkadarabot, és így ne fordíthassa el. Program szerint a következő sorrendben történt a megmunkálás:

- beömlők marása,

- villáskulcs rész,

- eszköztest,

- zárófedél eltávolító rész,

- 2,5 × 45ํ-os élletörés 3 részből.

Megfigyelhető a csipkézett szél a formaszerszámon (5. ábra). Ez a maró kopásának tudható be. Ilyenkor kialakul egy nyomott rész és a forgácsot nem dolgozza ki a mart résznél, hanem kissé felgyüri, ezt nevezzük sorjának. Ez éles és könnyen okozhat sérülést a szabad bőrfelületen.

Ezt követően a szerszámformát megtisztítottam, majd kézzel sorjátlanítottam.

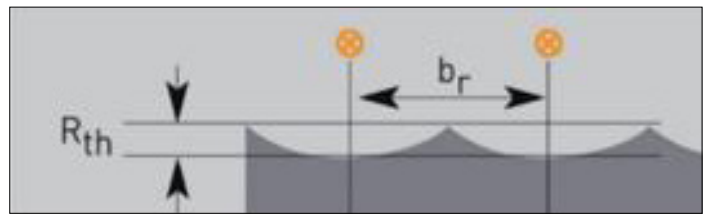

4. ábra. Elméleti felületi érdesség számítása simításhoz

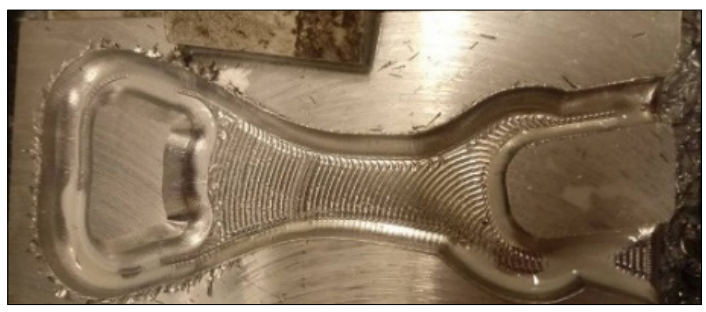

5. ábra. Kész munkadarab (forrás saját szerkesztés) 


\section{Kísérletek}

Első vizsgálatunk alapján az ömledék nem fekszi meg teljes mértékben a nagyolt formarészt. Enyhe beszívódás található a sörnyitó felőli oldalon (6. ábra). A beszívódás keletkezése a közvetkezőképpen zajlik. A termék külső síkjai a kedvezőtlen hütés következtében nem elég stabilak, a belső réteg hűlés közben behúzza. Esetünkben a 6 mm falvastagságból következik. Továbbá a beszívódás következhet a túl lassú hütésből adódóan is. A termék felső öntésű és gravitációs technológiából adódóan a hideg szerszámfalon fut végig. Látható, hogy a beömlő csatorna helyétől távolabb alakul ki.

Második vizsgálatunk alapján melegrepedés található a szerszám több részén (7. ábra). Ezesetben alapvetően metallurgiai problémáról beszélhetünk elsőként. A főbb oka a kristályosodási repedés kialakulásának, hogy az elsődleges kristályosodás során az ömledék megszilárdulása miatti feszültségek okozta alakváltozás meghaladja az alumíniumtermék alakváltozó képességét.

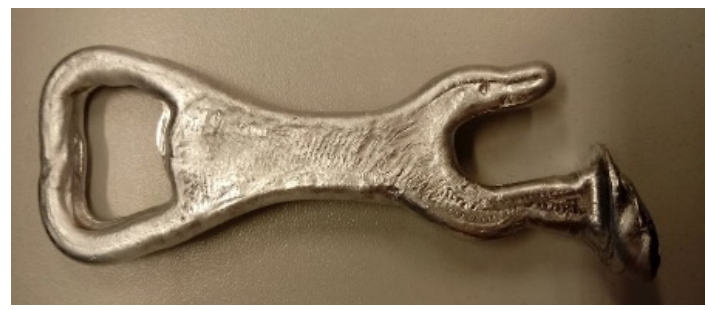

6. ábra. Kész termék öntve (forrás saját szerk.)

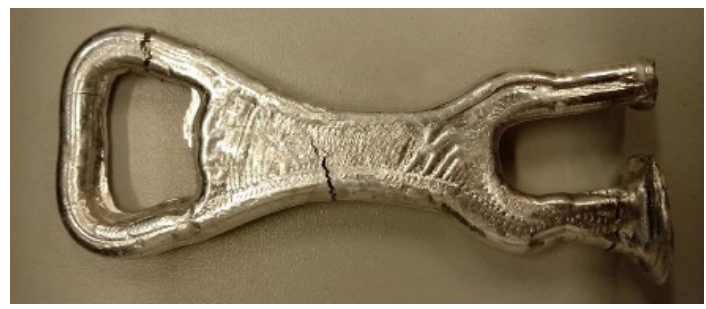

7. ábra. Repedés a készterméken (forrás: saját szerk.)

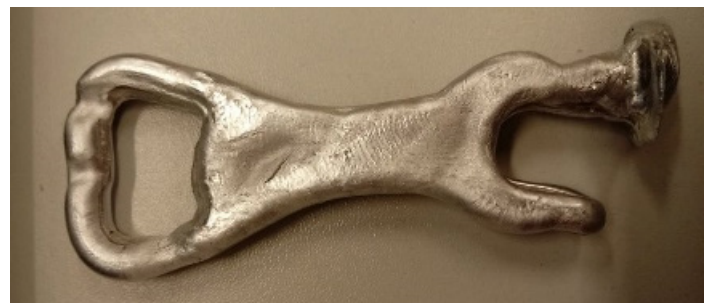

8. ábra. Beszívódás és melegrepedés (saját szerk.)
Harmadik vizsgálatunk alapján az ömledék nem tölti meg teljes mértékben a nagyolt formarészt. Enyhe beszívódás található a sörnyitó felőli nyakrészen, valamint a beszívódás területén melegrepedés. Erős beszívódás található a nyitó rész felfekvő felületén is (8. ábra).

Negyedik vizsgálatunk alapján repedést észleltünk, és töretet képeztünk, hogy lássuk a repedés terjedését. A töretből azt állapítottuk meg, hogy a repedés az anyag teljes keresztmetszetén jelen van, különböző mértékben (9. ábra).

Az ilyen jellegü ötvözetekre általánosan is jellemző, hogy a nagy szolidusz-likvidusz hőköz miatt - az ömledékállapotból történő lehűlés során - lényegesen több ideje marad a különböző alacsony olvadáspontú eutektikumok létrejöttének, s így a melegrepedés kialakulásának. Ezt a problémát könnyen orvosolhatjuk célszerüen választott hegesztőanyaggal, illetve már tervezési fázisban könnyebben hegeszthető ötvözet választásával [4]. A szerszámelőmelegítés mindkét oldalt egyenlő kell, hogy legyen ahhoz, hogy megfelelő öntvényt állítsunk elő.

Az ötödik kísérletünk alapján, az öntés eredményeként egy használható célszerszámot kaptunk, amely megfelel az elvárásainknak. A képen látszik, hogyan tölti ki a szerszámformát az ömledék, és hogyan veszi fel a nagyolt felület formáját.

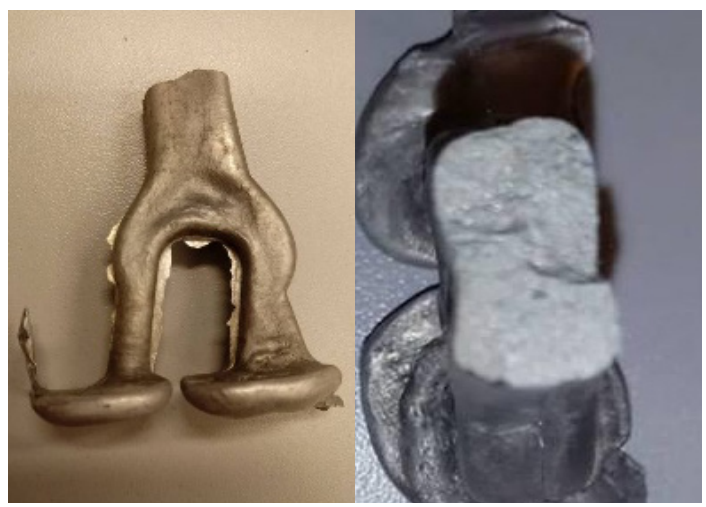

9. ábra. Repedés és töret (forrás: saját szerk.)

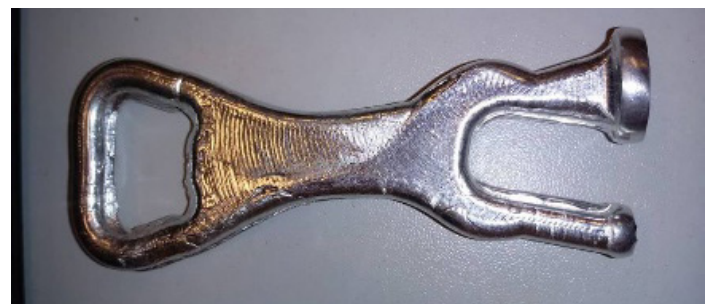

10. ábra. Megfelelő késztermék (forrás: saját szerk.) 


\section{Következtetések}

Teljesen behatárolt és minden peremfeltételnek megfelelő, gyártásra alkalmas szerszámot gyártottunk. Több kísérletet végeztünk különböző öntési paraméterek beállításával. Végül sikerült használható célszerszámot kiöntenünk. Az öntési paraméterek pontos meghatározása még nagy kihívás, de jelenlegi szakunk tanulmányaiban ez nem központi téma. Szeretnénk a közeljövőben egy bonyolultabb, nagyobb geometriájú szerszámot készíteni.

\section{Köszönetnyílvánítás}

A szerzők köszönetüket fejezik ki a Ceratizit Magyarország Kft.-nek a gyártáshoz szükséges szerszámok biztosításáért.

\section{Szakirodalmi hivatkozások}

[1] Varga F. (szerk.): Öntészeti kézikönyv. Műszaki Könyvkiadó, Budapest, 1964.

[2] G. T. Smith: CNC Machining Technology. Springer Verlag, 1993.

[3] Boza P., Burunyi P.: CNC forgácsolás 2. NMHSZFI, 2013.

[4] Fodorné Cserépi M., Pósalaky D.: Nagyszilárdságú acél és alumínium ötvözetek. Miskolc/Győr/Kecskemét, 2013. 